\title{
Analisis bahasa dan simbol pada iklan kemasan sabun mandi Shinzui
}

\author{
Lady Diana Yusri \\ Fakultas IImu Budaya Universitas Andalas \\ Email: Ladyyusri@yahoo.com
}

\begin{abstract}
This research aims to analyze the languages and symbols in the advertisement of soap packaging Shinzui. The data in this study used Japanese and English. The theory used to analyze the data is E-135(Sawirman, 2008:1). This theory consists of five stages: elaboration, representation, signification, exploration, and transfiguration.

This research is done chronologically based on three steps; they are collecting of the data, analyzing of the data, and presenting the result of analysis. In collecting the data used reading method with non-participant observation technique as basic technique and note-taking technique as follow-up technique. In analyzing the data used agih methods and padan methods. In agih methods using direct element dividing technique and In padan methods used and translational methods. The technique that used in padan methods was dividing element technique. In presenting the result of analysis the data informal methods.

After doing the analysis, the writer found that in Shinzui packaging soap is made from natural ingredients that will make this product user skin whiter and healthier. Beside that, these products have been clinically tested. A product reflects the culture in the society. There is an assumption that the pretty lady has skin like a Japanese woman. This advertisement is also represents that Japanese in particular has been popular in Indonesia.
\end{abstract}

Keywords : japanese, advertisement, languages, symbols

\section{Pendahuluan}

Bahasa adalah sebuah cara untuk mendapatkaninformasi.Melaluikegiatan berbahasa kita akan mendapatkan informasi tentang suatu kejadian atau peristiwa yang telah dikonstruksikan oleh sumber informasi. Biasanya orang memandang bahasa sebagai sebuah cara untuk mendeskripsikan dan memberikan informasi tentang dunia yang ada disekitar kita.

Bahasa sering digunakan sebagai alat untuk mempengaruhi seseorang untuk melakukan sesuatu seperti bahasa yang digunakan dalam mempromosikan sebuah produk dalam iklan. Kata iklan jika didefinisikan dalam KBBI adalah (1). Berita pesanan (untuk mendorong, membujuk) kepada khalayak ramai tentang benda dan jasa yang ditawarkan; (2) pemberitahuan kepada khalayak ramai mengenai barang dan jasa yang dijual, dipasang didalam media massa seperti surat kabar dan majalah (KBBI:322). Sementara itu, Sudiana (1986:1) memberikan batasan iklan sebagai salah satu bentuk komunikasi yang terdiri atas informasi dan gagasan tentang suatu produk yang ditujukan kepada khalayak secara serempak agar memperoleh sambutan yang baik. Iklan berusaha untuk memberikan informasi, membujuk dan meyakinkan. Jadi, dapat dikatakan bahwa iklan merupakan suatu sarana dalam upaya menawarkan barang atau jasa kepada khalayak ramai yang bertujuan untuk mempengaruhi masyarakat agar membeli produk yang di iklankan. Untuk mengiklankan suatu produk tentu dibutuhkan media. Ada banyak media yang digunakan untuk beriklan itu bisa melalui media elektronik seperti radio, televisi, internet dan 
sebagainya. Media cetak pun bisa menjadi pilihan yang ampuh untuk mempromosikan suatu produk seperti koran, majalah, baliho maupun media untuk mengemas produk tersebut.

Media yang digunakan untuk mengemas produk seperti kotak sabun adalah sekaligus untuk mengiklankan produk tersebut. Suatu iklan adalah suatu kegiatan menyampaikan berita, tetapi berita tersebut disampaikan atas nama pesanan pihak yang ingin agar produk atau jasa yang dimaksud disukai, dipilih, dan dibeli. Dalam menyampaikan berita selain berupa gambar, biasanya dalam sebuah iklan dalam media cetak diikuti dengan teks. Teks ini berfungsi untuk menyampaikan tujuan atau maksud yang ingin dipenuhi oleh sebagian atau seluruh isi teks (Andersen dalam Kaswanti, 2000:151).

Sehubungandenganiklanyang mempunyai gambar dan teks, Barthes dalam Sunardi (2002:181) menjelaskan bahwa teks mempunyai fungsi untuk anchorage 'membatasi' dan relay 'mempercepat'. Fungsi anchorage ini dimaksudkan untuk membatasi pembaca untuk segera menghubungkan signifier (gambar) dan signified. Fungsi relay dimaksudkan mempercepat pembaca memahami signifier dan menghindari ketidakjelasan makna denotatif.

Sehubungan dengan signifier dan signified, Saussure menjelaskan bahwa tanda terdiri dari: bunyi-bunyian dan gambar, disebut signifier atau penanda, dan konsep-konsep dari bunyi-bunyian dangambar,disebutsignified.Dalam

berkomunikasi, seseorang menggunakan tanda untuk mengirim makna tentang objek dan orang lain akan menginterpretasikan tanda tersebut. Objek bagi Saussure disebut "referent". Hampir serupa dengan Peirce yang mengistilahkan interpretant untuk signified dan object untuk signifier, bedanya Saussure memaknai "objek" sebagai referent dan menyebutkfannya sebagai unsur tambahan dalam proses penandaan. Contoh: ketika orang menyebut kata "anjing" (signifier) dengan nada mengumpat maka hal tersebut merupakan tanda kesialan (signified). Begitulah, menurut Saussure, "Signifier dan signified merupakan kesatuan, tak dapat dipisahkan, seperti dua sisi dari sehelai kertas." (Sobur, 2006).

Pada tulisan ini akan dibahas perihal bahasa dan simbol yang terdapat pada kemasan sabun mandi Shinzui. Produk ini dipilih karena beberapa alasan. Pertama, teks pada kemasan sabun ini menggunakan bahasa Jepang, sementara produk ini beredar di Indonesia. Kedua, kemasan produk ini sangat menarik dilihat dari gambar dan teksnya. Tulisan ini akan dianalisis dengan pendekatan teori e-135. Penulis menggunakan teori ini karena dengan menggunakan teori ini terdapat lima tahap yang dapat mengeksplorasi hal-hal yang terdapat dalam kemasan dan hal-hal lain yang berhubungan dengan Jepang.

\section{Metode Penelitian}

Penelitian ini dilihat dari pokok masalah penelitian, yaitu analisis bahasa dan simbol yang terdapat dalam kemasan sabun mandi Shinzui. jelaslah bahwa dari aspek substansi bahasanya adalah bahasa tulisan, bukan bahasa lisan. Dari sifat analitisnya, penelitian ini dilakukan dengan deskriptif yang berusaha untuk menerangkan dan mengamati gejala bahasa yang diteliti. Nida (1963:1) menjelaskan analisis deskriptifitu sebagai berikut: "The descriptive analyst must be guided by certain very fixed principles if he is to be objective in describing accurately any language or part of any language."

Dari pendapat Nida di atas, dapat dipahami bahwa sebuah analisis deskriptif itu, datanya harus sesuai dengan sumber yang diteliti, kemudian yang dikaji adalah bentuk dan fungsi dari hal yang diteliti. Pada umumnya, prinsip suatu bahasa itu adalah universal, jadi peneliti harus mempunyai referensi terlebih dahulu dari bahasa lain.

Sehubungan dengan bahasa selalu mengalami perubahan, diperlukan suatu batasan yang jelas dalam penelitian.

Setiap penelitian pasti mempunyai tahaptahap yang harus dilalui sebagai suatu proses sebelum menemukan hasil akhirnya. Ada tiga tahapan yang harus dilalui dalam penelitian ini, yaitu penyediaan data, penganalisisan data, dan penyajian hasil analisis data (Sudaryanto, 1993:57).

Metode penyediaan data dalam penelitian ini adalah metode simak (Sudaryanto, 1993:132), atau lebih tepat dikatakan dengan metode baca karena sumber data dalam penelitian ini adalah data tertulis. Teknik dasar yang digunakan adalah teknik sadap, yaitu pelaksanaan metode simak dengan menyadap penggunaan bahasa seseorang atau beberapa orang. Pada penelitian ini, bahasa yang disadap berbentuk tulisan. 
Teknik lanjutan penyediaan data dilakukan dengan teknik Simak Bebas Libat Cakap (SBLC). Kegiatan ini dilakukan dengan menyimak penggunaan bahasa tanpa ikut berpartisipasi dalam proses pembicaraan. Dalam teknik ini, peneliti tidak dilibatkan langsung untuk ikut menentukan pembentukan dan pemunculan calon data, kecuali hanya sebagai pemerhati-pemerhati terhadap calon data yang terbentuk dan muncul dari peristiwa kebahasaan yang berada di luar darinya (Sudaryanto, 1993:134).

Teknik lanjut yang dapat digunakan untuk penyediaan data dalam penelitian ini adalah teknik catat (Sudaryanto, 1993:135). Pencatatan data yang dimaksudkan adalah memilah dan memilih data yang terdapat pada sumber data, kemudian diklasifikasikansesuaidengankeperluan penelitian. Hal ini dilakukan agar pada tahap akhir menganalisis data penelitian lebih mudah dilakukan.

\section{Metodeyangdigunakanuntuk} menganalisis data pada penelitian ini adalah metode agih dan metode padan. Metode agih yang digunakan mengacu pada pengertian yang dikemukakan oleh Sudaryanto (1993:15). Pada metode agih, alat penentunya merupakan bagian dari bahasa itu sendiri. Metode padan adalah metode analisis data yang alat penentunya berada di luar, terlepas, dan tidak menjadi bagian bahasa (langue) yang bersangkutan atau diteliti (Sudaryanto, 1993:13). Jadi, alat penentu pada penelitian ini dilihat dari bahasa Jepang itu sendiri dan diluar bahasa Jepang, yaitu bahasa Indonesia.

Teknik dasar yang digunakan dalam metode agih untuk menganalisis data adalah Teknik Bagi Unsur Langsung (BUL) yang dikemukakan oleh Sudaryanto (1993:31), yaitu dengan membagi satuan lingual datanya menjadi beberapa bagian atau unsur dan unsur-unsur bersangkutan dipandang sebagai bagian yang langsung membentuk satuan lingual yang dimaksud.

Selanjutnya, metode padan yang digunakan dalam penelitian ini adalah metode padan translasional.Metodepadantranslasional digunakan karena alat penentunya berupa bahasa lain. Bahasa lain yang dimaksudkan adalah bahasa di luar bahasa yang diteliti. Untuk menentukan peran semantis, dipakai metode padan referensial, yaitu metode padan yang alat penentunya berupa referen bahasa. Referen bahasa adalah kenyataan atau unsur luar bahasa yang ditunjuk satuan kebahasaan (Kridalaksana, 2008:208).

Teknik yang digunakan adalah teknik pilah unsur penentu, yaitu teknik analisis data dengan cara memilah-milah satuan kebahasaan yang dianalisis dengan alat penentu berupa daya pilah yang bersifat mental yang dimiliki oleh penelitinya (Sudaryanto, 1993:21; Kesuma, 2007:51). Sesuai dengan metode yang digunakan, daya pilah yang digunakan adalah daya pilah translasional yang berwujud bahasa lain sebagai penentu.

Prosedur yang terakhir adalah penyajian hasil data. Untuk menyajikan hasil analisis data, ada dua macam metode yang diterapkan, yaitu metode penyajian informal dan metode penyajian formal. Kedua metode ini digunakan untuk menyajikan kaidah-kaidah yang ada pada bahasa yang diteliti (Sudaryanto, 1993:145). Secara teknis, metode informal dinyatakan dalam bentuk pernyataan verbal yang singkat, tepat, dan jelas, sedangkan metode formal secara teknis dapat dinyatakan dalam bentuk lambang-lambang. Hasil penelitian dalam tulisan ini akan disajikan dengan kata-kata yang disajikan secara ringkas dan jelas yang secara metodologis disebut dengan metode informal.

\section{Sekilas mengenai e-135}

E-135merupakansingkatandari

Eksemplar 135. Huruf E pada E-135 menyimbolkan eksemplarsekalipun E-135 memang menjadikan data elektronik sebagai data "hiperteks" pada salah satu tahapan (tahapan eksplorasi). Angka 1 pada E-135 menyimbolkan landasan ontologis/filosofis (hermeneutika), angka 3 menyimbolkan revisi pendekatan wacana terkini (kritis, dekonstruksionis, cultural studies), serta angka 5 menyimbolkan tahapan analisis (elaborasi, representasi,signifikasi,eksplorasi,dan transfigurasi) sekaligus landasan objek material dan formal yang masing-masingnya diberi penjelasanontologis,epistemologis, dan aksiologis.

E-135 diciptakan oleh Dr. Sawirman, S.Pd, M.Hum, staf pengajar di Universitas Andalas. Pada mulanya e-135 ini digunakan untuk membedah simbol lingual wacana politik Tan Malaka (salah seorang tokoh perenial asal Minangkabau) untuk keperluan disertasi doktoral 
di Universitas Udayana tahun 2005. Diseminasi dan sosialisasi e-135 ini sudah dilakukan dalam berbagai forum dan jurnal ilmiah. E-135

ditawarkan sebagai salah satu "paradigma alternatif" dan masih tetap diujikan ke beragam objek/fenomena wacana, teks, semiotik, dan linguistik. Sebagai titik tolak pemahaman, lima tahapan analisis beserta objek-objek material dan formalnya dibahas pada uraian-uraian berikut: 1. Tahap elaborasi

Padatahapelaborasimemaknai teks/wacana sebagai sebuah produk dalam wujudnya secara fisik ("object oriented"). Objek material atau data yang digunakan adalah teks (dalam artian teks atau wacana yang ditelaah, bukan intrateks, interteks atau hiperteks). Tahap elaborasi adalah refeleksi sistem langue, determinisme teori sistem (mencari makna dari sumber standar dan hukum keteraturan), kategori benar-salah, linear, bahasa sebagai cermin monolitik, abstraksi bentuk, dan logika operasi praktis (sesuai nilai tukar) yang memposisikan teks sebagai sebuah instrumen.

2. Tahap representasi

Pada tahap representasi Sawirman menjelaskan bahwa tahap ini merupakan hubungan antara bahasa sebagai tanda dan konsep mental yang dipresentasikannya dengan realitas yang ada tentang fakta, manusia, keadaan, peristiwa, benda nyata, atau objek (fiktif). Sebuah wacana merupakan hasil konstruksi pengarang dengan percampuran faktor subjektivitas, ideologi, kultur, dan nilai yang dianut pembuat teks.

Konstruksi realitas yang dibuat pemproduksi teks dari berbagai objek atau peristiwa menjadi wacana bermakna dan dapat menentukan citra terhadap objek atau peristiwa dimaksud.

3. Tahap signifikasi

Tahap signifikasi dalam e-135 ini menyediakan ruang bagi pembaca seluas-luasnya untuk melacak makna terhadap representasi mentalpemproduksiteks. Tahapini mengharapkan seorang analis teks agar memposisikan diri sebagai seorang pembaca teks yangkritisuntukmen-decodeatau menginterpretasikan makna teks.

\section{Tahap eksplorasi}

Istilah eksplorasi yang digunakan dalam e135 mengindikasikan agar penjelajahan makna tanda/simbol lingual dianalisis sampai tahapan makna terdalam(depth meaning) seperti harapan Baudrillard. Pendekatan hipersemiotika (hypersign) dan hiperteks (hypertext) diberdayakan pada tahap ini.

\section{Tahap transfigurasi}

Strategipemaknaanpadatahap

transfigurasi dapat dilakukan melalui dua cara, yakni (1) strategi pemaknaan rekonstruksionis dan (2) strategi pemaknaan dekonstruksionis. Tahapan transfigurasi dapat pula disintesiskan dengan pernyataan, interpretasi, dan abstraksi dengan memperhatikan semua pesan-pesan kunci, fungsifungsi kunci, perintah-perintah kunci, dan katakata kunci yang terefleksi dari hasil analisis tahapan elaborasi, representasi, signifikasi, dan eksplorasi.

\section{Analisis Bahasa dan Simbol Pada Kemasan Sabun Mandi Shinzui: Tinjauan Teori e-135}

Salah satu media untuk mempromosikan produk adalah kemasannya. Kemasan yang baik akan merepresentasikan produk di dalamnya. Shinzui adalah nama produk kecantikan, yang mempunyai produk seperti body lotion, sabun mandi yang batangan dan yang cair. Pada tulisan ini akan dibahas mengenai bahasa dan simbol yang terdapat pada kotak sabun batangan Shinzui. Untuk memperjelas bahasa dan simbol yang akan dianalis, berikut ini adalah tampilan kotak sabun mandi Shinzui.

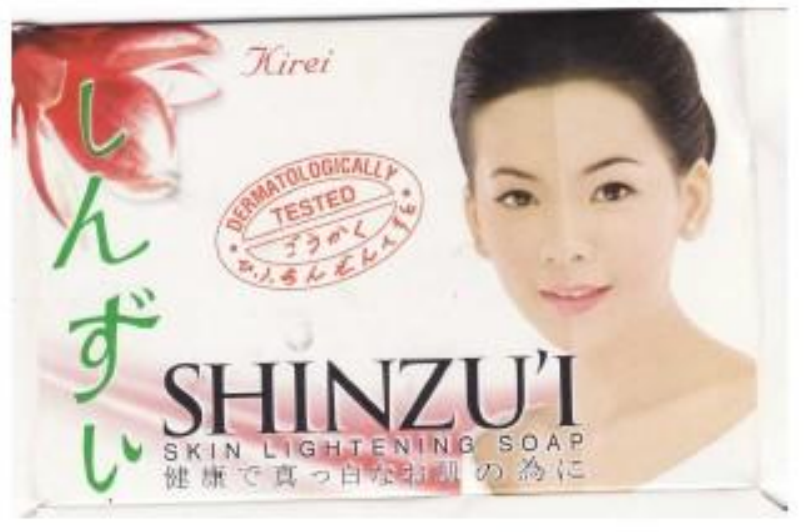

$\mathrm{Ga}$

mbar 1. Kemasan sabun Shinzui

Dari kemasan produk diatas terdapat tulisantulisan yang akan dianalisis dalam tulisan ini dengan menggunakan analisis wacana e-135, yaitu
1. しんずい Shinzui
2. kirei
3. ごうかくgoukaku 
4. ひふあんぜんですと hifu anzen desu to

5. 健康で真っ白なお肌の為に kenkou de masshirona ohada no tameni

Sementara itu, dikemasan ini juga terdapat beberapa simbol seperti seorang wanita yang wajahnya terdapat dua warna, bunga merah yang sedang merekah, dan tulisan Shinzui yang diberi warna hijau. Berikut ini adalah análisis data berdasarkan teori e-135.

\section{Tahap Elaborasi}

Tahap ini merupakan tahapan linguistik mikro pada bagian data yang akan di analisis. Tahap ini memandang teks sebagai wujud material yang merupakan produk dari wacana itu sendiri. Wujud material pada kotak sabun ini bisa kita lihat dari huruf yang dipakai. Yang menonjol dari penggunaan huruf adalah huruf Jepang. Dalam bahasa Jepang terdapat tiga aksara, yakni Kanji, huruf Hiragana dan huruf Katakana.

Huruf Hiragana dan huruf Katakana biasa disingkat menjadi huruf Kana. Satu buah huruf kana pada umumnya mewakili sebuah mora (satuan bunyi bahasa Jepang). Kanji menunjukkan artinya dan bunyinya. Bunyi dalam bahasa Jepang berbentuk suku kata jika ditulis dengan huruf bahasa Jepang. Suku kata tersebut merupakan suku kata terbuka, yaitu diakhiri dengan vokal. Sehingga keistimewaan bunyi bahasa Jepang tidak ada bunyi yang diakhiri dengan konsonan (suku kata tertutup), kecuali [N] saja (Sutedi, 2003:14).

Kemasan produk ini terdapat beberapa tulisan yang ditulis dengan huruf hiragana, yaitu しんずい Shinzui、ごうかく goukaku、ひふあ んぜんですと hifu anzen desuto. Sedangkan yang memakai huruf campuran antara huruf kanji dan hiragana adalah 健康で真つ白なお肌為に。 Huruf romaji digunakan untuk menuliskan kata kirei, tested dan dermatology.

Produk yang diiklankan dalam kemasan ini diberi nama しんずい Shinzui. しんずい terdiri dari empat mora yaitu し[shi]、ん[N]、ず[zu]、 い [i]. Kata Shinzui ini ditulis dengan menggunakan huruf Jepang yaitu hiragana. Huruf hiragana adalah huruf yang diciptakan oleh bangsa Jepang sendiri dan ini membedakannya dengan huruf yang berasal dari China yaitu Kanji. Kata Shinzui sendiri juga mempunyai huruf kanji yaitu 真髄 yang dalam bahasa Indonesia berarti inti sari, inti pati (Matsura, 1994:933). Pencirian produk ini dengan menggunakan warna hijau menandakan bahwa produk ini berasal dari sari pati yang diambil dari alam. Selain itu pencirian juga terdapat pada tulisan hiragana. Hal ini bertujuanuntukmemberitahukankepada penggunanya bahwa produk ini adalah buatan Jepang.

\section{Tahap Representasi}

Pada tahap ini menganalisis hubungan bahasa sebagai tanda yang menggambarkan realitas yang ada tentang manusia, fakta, peristiwa dan lainnya. Tahapan ini mengkaji hubungan interteks dalam wacana. Pada tahap ini kita akan melihat adanya hubungan antara Shinzui dengan kirei yang bermakna cantik, indah elok, bagus (Matsura, 1994:500).

Kata Shinzui jika disamakan dengan kirei berarti orang yang menggunakan sabun ini akan menjadi kirei atau cantik. Representasi kata cantik yang digambarkan dalam kemasan ini adalah seorang wanita yang berkulit putih, langsing, tanpa menggunakan hiasan wajah yang mencolok. Hal ini menimbulkan kesan bahwa adalah kecantikan wanita ini berasal dari kulitnya yang bagus.

\section{Tahap Signifikasi}

Tahap ini merupakan tahap interpretasi teks secara kritis. Tahapan ini merupakan gabungan antara tahapan semiotik dan analisis kritis. Pada tahap ini peneliti akan menginterpretasikan kata Shinzui dengan goukaku dan hifu anzen desu to. Kata goukaku ini diartikan tested dalam bahasa Inggris, Sedangkan dalam bahasa Indonesia gokaku berarti berhasil, lulus (Matsura, 1994:222). Dengan kata lain, produk ini telah melewati rangkaian tes untuk keamanan kulit pemakainya.

Kata berikutnya adalah yang dalam bahasa Inggris yaitu dermatology 'aman bagi kulit' . Sementara itu, dalam bahasa Jepang kata dermatology diwakili dengan kata-kata hifu anzen desuto. Perhatikan uraian berikut ini.
Hifu-anzen desu - to
Kulit-aman Kopula- Partikel 'aman bagi kulit'

Penekanan aman bagi kulit diwakilkan pada partikel to. Salah satu fungsi partikel to adalah menunjukkan kepastian yang akan terjadi menyusul perbuatan yang mendahuluinya (Chino, 
2001:28). Jadi, dengan menambahkan partikel to, konsumen produk ini diberi keyakinan bahwa produki ini sangat aman karena telah lulus uji untuk keamanan kulit manusia. Hal ini menjadi penting karena kulit manusia itu bermacammacam ada kulit normal, kering dan sensitif. Jika salah dalam penggunaan, bukannya kecantikan yang diperoleh yang akan timbul juga kulit kemerahan, menghitam, dan tidak halus lagi.

\section{Tahap Eksplorasi}

Tahap ini merupakan analisis tanda secara mendalam, dimana tanda dieksplorasi secara mendalam. Pada tahapan ini penulis akan melihat hubungan antara Shinzui dengan kata-kata skin lightening soap dan 健康で真っ白なお肌の為に kenkoude masshirona ohadano tameni.

Tulisanskinlighteningsoapjika diterjemahkan kedalam bahasa Indonesia dapat berarti sabun pencerah kulit. Sehingga, makna yang timbul dengan menggunakan produk ini kulit akan menjadi lebih cerah. Selanjutnya, di dalam bahasa Jepang, produk ini sendiri jika di uraikan sebagai berikut;

\section{健康で真っ白なお肌の為に \\ Kenkou-demasshironao \\ -hada-no tameni \\ Sehat-Partikel benar-benar putih \\ Honorifik-kulit-Gen untuk \\ 'Untuk kulit anda yang benar-benar putih} dan sehat.'

Seperti yang kita bahas pada tahap diatas adalah adanya hubungan kesehatan dengan sabun ini yaitu kata kenkou 'sehat'. Konsumen diberi keyakinan bahwa produk ini baik untuk kesehatan. Selanjutnya, terdapat kata adalah masshirona. Kata Masshirona berarti putih bersih, putih mulus, putih betul (Matsura: 1994: 612). Maashirona berasal dari kata shiroi yang berarti putih dengan diberi prefiks ma- atau kanji 真 yang berarti benarbenar. Maka, dari penjelasan di atas menunjukkan hubungan antara Shinzui dengan shiroi 'putih'.

Selanjutnya, Jika dihubungkan antara Shinzui, kirei 'cantik' dan shiroi 'putih', maka pemakai produk Shinzui ini akan menjadi cantik dan putih. Hal ini digambarkan oleh gambaran wanita yang ada disebelah yaitu wanita yang mempunyai dua warna kulit yaitu agak kecoklatan dan putih. Ini menandakan bahwa setelah memakai ini maka kulit yang agak gelap akan menjadi lebih putih.

Simbol yang digunakan lainnya adalah bunga yang berwarna merah yang sedang mekar, hal ini melambangkan sosok seorang wanita yang cantik, indah dan menarik perhatian. Jadi bisa kita lihatdarisemuasimbolyangada merepresentasikan seorang wanita yang cantik, putih dan menarik perhatian orang yang melihatnya.

Selain itu, wanita yang digambarkan adalah seorang wanita Jepang yang masih muda. Wanita Jepang dipilih karena pada umumnya wanita Jepang pada umumnya berkulit putih bersih alami. Alasan mengapa yang dipilih wanita Jepang mewakili produk ini, karena masyarakat Indonesia pada umumnya mengetahui produkproduk Jepang yang ada di Indonesia berkualitas. Bahkan, produk buatan Jepang dianggap sebagai produk yang terbaik di dunia dan sejajar dengan produk negara maju lainnya (Seng, 2006: 80).

\section{Tahap Transfigurasi}

Tahap ini merupakan tahap pemetaan makna, yaitupenggabunganantarinterpretasi pemproduksi kode, interterpretasi kode itu sendiri dan interpretasi yang pengonsumsi kode tersebut. Produk sabun mandi ini diproduksi oleh PT Bina Karya Prima, Jakarta. Diperuntukkan kepada wanita Indonesia yang ingin berkulit lebih putih. Kulit putih bagi masyarakat Indonesia berarti cantik dan menarik sehingga banyak orang-orang yang menginginkan kulitnya lebih cantik.

Pemilihan bahasa Jepang dan bahasa Inggris pada produk ini merepresentasikan bahwa pemakai produk ini yaitu masyarakat Indonesia adalah masyarakat yang pengetahuan bahasa asingnya cukup baik dan menuju masyarakat modern. Hal ini berarti pemakai produk ini dianggap bahwa kehidupannya sudah modern dan berpendidikan.

Jadi,dari tahap-tahap di atas dapat

dipetakan sebagai berikut;

Shinzui= kirei 'cantik, indah elok, bagus'

Shinzui= shiroi 'putih'

Shinzui= gokaku 'lulus uji', hifu anzen desu

to 'aman untuk kulit'

Shinzui= kenkoude masshirona ohadano tameni 'Untuk kulit yang putih bersih dan sehat'. 
Shinzui $=$ produk Jepang yang berkualitas untuk masyarakat Indonesia yang berpendidikan dan modern

\section{Kesimpulan}

E-135 harus dijadikan sebagai ranah baru dalam linguistik. Menelaah suatu teks dengan E135 akan mampu mengungkap makna terdalam yang terdapat pada sebuah teks. Selain teks e-135 dapat juga mengungkap simbol-simbol yang menyertai teks tersebut. Kelebihan lainnya e-135 bisa digunakan untuk membedah bahasa dalam berbagai media.

Media pada tulisan ini adalah kemasan sabun mandi Shinzui. Sebuah produk merupakan representasi dari zaman terbentuknya produk ini, begitu juga halnya dengan produk ini. Dengan katalainkemasandarisabunini merepresentasikan masyarakat pengguna sabun ini yaitu masyarakat Indonesia.

Masyarakat Indonesia pada umumnya, khususnya bagi wanitanya sangat ingin berkulit putih, mulus, karena dengan kulit putih akan menjadimenarikdancantik.Untuk merepresentasikan hal ini produk shinzui produk ini mengunakan simbol seorang wanita yang berwajah Jepang dengan kulit yang menjadi cerah.
Pilihan bahasa yang digunakan dalam produk ini, yaitu bahasa Jepang dan bahasa Inggris merepresentasikan bahwa bahasa asing khususnya bahasa Jepang telah dikenal oleh masyarakat Indonesia.

Peneliti berharap penelitian ini dapat memberikan arti bagi penelitian berikutnya, baik sebagai bahan perbandingan maupun sebagai bahan acuan penelitian. Selain itu, Peneliti berharap ke depannya akan lebih banyak penelitian yang berhubungan dengan bahasa dan media dengan data berbahasa Jepang.

\section{REFERENCES}

[1] Chino, Naoko. 2001. Partikel Penting Bahasa Jepang. Jakarta: Kesaint Blanc.

[2] KBBI (Kamus Besar Bahasa Indonesia).1988. Jakarta: Balai Pustaka.

[3] Matsura, Kenji. 1994. Nihongo Indonesiago Jiten. Jepang: Kyoto Sangyo University Press.

[4] Nida, Eugene A.1965. Morphology: The descriptive Analysis of Words. The University of Michigan Press.

[5] Sawirman, 2008. "Selamatkan Linguistik dengan e-135". Disampaikan pada National Seminar on Language Literature and Language Teaching di FBSS UNP Padang, tanggal 10-11 Oktober 2008.

[6] Seng, Ann Wan. 2007. Rahasia Bisnis Orang Jepang. Jakarta: Hikmah 